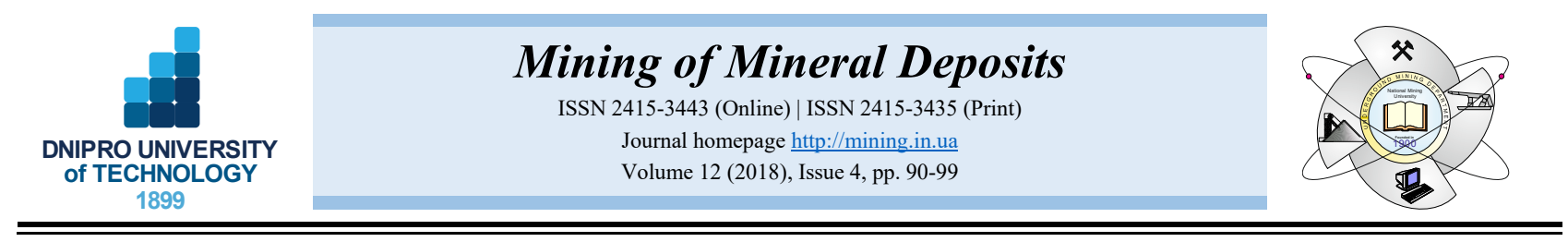

UDC 622.831 .325 .3

https://doi.org/10.15407/mining12.04.090

\title{
MECHANISM CONVERSION PROCESS AND TIMELINESS OF N2-ECBM
}

\author{
L. Chen ${ }^{1,2^{*}}$, T. Yang ${ }^{1}$, H. Yang ${ }^{2}$, L. Wang ${ }^{2}$ \\ ${ }^{I}$ Northeastern University, Shenyang, China \\ ${ }^{2}$ Henan Polytechnic University, Jiaozuo, China \\ *Corresponding author: e-mail clwlf@,163.com, tel. +8603913986269
}

\begin{abstract}
Purpose. Based on the technology by which methane drainage is strengthened under gas injection, to examine the process of gas injection and the mechanism of action.

Methods. Physical simulation experiment method, using the self-built coal seam and gas injection displacement experimental device, the experiment of layered pre-compression forming coal samples under vertical stress loading conditions and under the conditions of different gas injection pressures.
\end{abstract}

Findings. The experiment on $\mathrm{N}_{2}$-ECBM is a dynamic process and has time effects. In the overall process, the rate of replacement was more than $60 \%$, and the rate of displacement was less than $40 \%$.

Originality. According to the behavior of nitrogen injection in the coalbed, an assessment of displacement effects under gas injection and a quantitative evaluation of the replacement effect were presented. In every stage of the process, the replacement effect is dominant, while the role of displacement is of secondary importance.

Practical implications. The experimental results have great guiding significance for optimization of gas parameters and gas source selection for gas injection flooding in underground coal seams.

Keywords: mechanism of $\mathrm{N}_{2}$-ECBM, timeliness, displacement effect, replacement effect, quantitative study, coal mine

\section{INTRODUCTION}

Coal mine gas injection is used to promote coalbed methane drainage with such technologies as Enhanced Oil Recovery (EOR) and Carbon Capture, Utilization and Storage (CCUS). In particular, $\mathrm{CO}_{2}$ geological storage technology not only reduces greenhouse gas emissions but also improves the recovery rate of CBM.

At the end of the $20^{\text {th }}$ century, $\mathrm{CO}_{2}$ was injected for increasing coalbed methane $\left(\mathrm{CO}_{2}-\mathrm{ECBM}\right)$ in the United States' San Juan Basin; this approach was the prelude to CBM coalbed gas injection in the field driving the technology for methane (Reeves, 2005). In subsequent years, the United States, Canada, Japan, EU and China have started research and conducted ECBM field trials of various scale (Van Bergeb et al., 2002; Gunter, Mavor, \& Robinson, 2005; Reeves, 2005; China United Coal..., 2007; Shi, Durucan, \& Fujioka, 2008; Hong-min, 2010; Zhi-ming, Xiao-chun, \& Hong, 2010; Oudinot et al., 2011; Godec, Koperna, \& Gale, 2014; Masoudian, Airey, \& El-Zein, 2014). The US carried out $\mathrm{CO}_{2}$-ECBM field test in San Juan Basin, Black Warrior Basin, Illinois Basin, and Central Appalachian Basin. In Hokkaido (Japan), Poland, and Alberta (Canada), field trials of different sizes were also carried out. China United Coalbed Methane Co. Ltd. was the first mine that conducted $\mathrm{CO}_{2}$ injection into the ground in Jin-Cheng, China. Next, Zhi-ming, Xiao-chun, \& Hong (2010) carried out the low-pressure $(<0.6 \mathrm{MPa}) \quad \mathrm{N}_{2}$-ECBM test in Ping Dingshan Coal Mine, Yangquan Coal Mine.

To make this technology more practical and applicable to production, scientists have conducted considerable theoretical research, especially regarding the mechanisms of enhanced coalbed methane recovery under gas injection (Busch, Krooss, Gensterblum, van Bergen, \& Pagnier, 2003; Fitzgerald et al., 2005) have suggested that the adsorption capacity of coal to $\mathrm{N}_{2}, \mathrm{CH}_{4}$ and $\mathrm{CO}_{2}$ becomes stronger (Katayama, 1995) suggested that the mechanism by which $\mathrm{CO}_{2}$ can displace $\mathrm{CH}_{4}$ is based on the fact that coal adsorption energy to $\mathrm{CO}_{2}$ is better than that to $\mathrm{CH}_{4}$, because of what the seam $\mathrm{CH}_{4}$ recovery is improved. $\mathrm{N}_{2}$ can replace $\mathrm{CH}_{4}$ due to the changes in the partial pressures of the two gases, thereby forming a new adsorption equilibrium (Clarkson \& Bustin, 2000) assumed that when a non- $\mathrm{CH}_{4}$ gas is injected into the coal seam, it will compete for adsorption space with $\mathrm{CH}_{4}$ or reduce the partial pressure of $\mathrm{CH}_{4}$ in the free gas, thus contributing to $\mathrm{CH}_{4}$ desorption from the coal seam and

(C) 2018. L. Chen, T. Yang, H. Yang, L. Wang. Published by the Dnipro University of Technology on behalf of Mining of Mineral Deposits.

This is an Open Access article distributed under the terms of the Creative Commons Attribution License (http://creativecommons.org/licenses/by/4.0/),

which permits unrestricted reuse, distribution, and reproduction in any medium, provided the original work is properly cited. 
increasing the gas production rate of $\mathrm{CH}_{4}$ (Shi-yue \& Yong-yi, 2000) studied the stimulation mechanism of exploitation of coalbed methane by gas injection based on the diffusion, percolation and multicomponent adsorption equilibrium theory. He claimed that there are three components to such mechanism of action: first, by increasing the energy of seam $\mathrm{CH}_{4}$ flow through gas injection; second, by increasing desorption rate and desorption through the competitive adsorption and displacement effect; and third, by increasing permeability through changes in the pore structure of the coal seam (Long-jun, Cheng-lun, \& Xue-fu, 2000) stated that this approach reduces the $\mathrm{CH}_{4}$ partial pressure in the coal seam after injecting $\mathrm{N}_{2}, \mathrm{CO}_{2}$ or flue gas into coal seam and adds impetus to the flow of $\mathrm{CH}_{4}$ to overcome the flow resistance of a coal seam with low permeability (Shu-heng, Qi, \& Da-zhen, 2002) established that this technology essence is to inject energy into the coal seam, change the pressure transmission characteristics and increase or maintain the diffusion rate. In addition, the injection of gas will produce competitive adsorption, which, under high pressure, will induce the formation of new cracks, thereby increasing permeability (Xing-zhou, Yong-yi, \& Shi-yue, 2000; Jian-guang \& Xiao-guang,2004; Xiaoguang \& Zhan-jun, 2004; Xi-jian, Li-yong, \& Hao, 2007; Wen-ming \& Sui-an, 2008) have suggested that $\mathrm{N}_{2}$ reduces the partial pressure of $\mathrm{CH}_{4}$ when it is injected into coal seam and that almost all of the $\mathrm{CH}_{4}$ can be extracted or expelled by the $\mathrm{N}_{2}$. When $\mathrm{CO}_{2}$ was injected into the coal seam, because of its strong adsorptive force, it produced competitive adsorption with the $\mathrm{CH}_{4}$, which was adsorbed in coal matrix micro pore, and, after a period of time, $\mathrm{CO}_{2}$ could displace the $\mathrm{CH}_{4}$ (Shang-chao \& Zhi-xu, 2008; Guo-ting, 2009) supposed that ECBM increase is due to the following mechanism: first, the injection of gas reduces the partial pressure of $\mathrm{CH}_{4}$ that promotes $\mathrm{CH}_{4}$ desorption; second, the flow of gas expels $\mathrm{CH}_{4}$ to production wells; third, the injected gas is maintained at a higher pressure gradient than simply pumping and this increases the effect of flow rate; and fourthly, the injection gas maintains a higher pore pressure, which increases the permeability of the coal seam (Zhi-ming, Xiaochun, \& Hong, 2010) considers that there are two mechanisms of $\mathrm{CO}_{2}$ flooding coalbed methane: the first is replacement, by which there is adsorption competition between the displacement gas $\left(\mathrm{CO}_{2}\right)$ and $\mathrm{CH}_{4}$, replacing $\mathrm{CH}_{4}$ molecules and promoting $\mathrm{CH}_{4}$ desorption, while reducing the partial pressure of $\mathrm{CH}_{4}$ and promoting $\mathrm{CH}_{4}$ desorption further; the second is expulsion, wherein the injected gas is maintained at a higher pressure gradient than simply pumping and this increases the effect of flow rate and expels $\mathrm{CH}_{4}$ to production wells (Hong-min, 2010) proposed the following mechanisms by which injection gas replaces seam $\mathrm{CH}_{4}$ : the replacement adsorption - desorption effect of injection gas, the contained portable/displacement effect of airflow, dilution and diffusion and the AR expansion effect of injection gas. The carrier of gas stream and flooding effects play a dominant role, while the replaced $\mathrm{CH}_{4}$ occupies a smaller proportion.

In summary, scholars have conducted considerable research on the mechanism of enhancing coalbed methane recovery by gas injection. These theories provide great support for the application and development of the technology, but coal seam gas injection is a dynamic process in which the contributions of a variety of mechanisms of action can also change. In engineering applications, it is important to know whether it is the choice of a different gas to increase its replacement of coalbed $\mathrm{CH}_{4}$ or the choice of the right pressure and gas injection flow rate to improve gas flow conditions in the coal seam, which can improve the airflow displacement effect. Therefore, the roles of and quantitative research related to coal seam gas injection mechanisms are still theoretical problems to be solved. This paper aims to determine these roles through laboratory simulation experiments to analyze the replacement and displacement effect of the gas injection process and carry up quantitative research to reveal the leading mechanisms of the seam gas injection process, thereby providing an experimental and theoretical basis for the engineering application of coal seam gas injection.

\section{EXPERIMENTAL METHODS}

\subsection{Experimental devices}

The experimental platform includes the following: experimental chamber, stress loading system, gas injection system, vacuum pumping system, pressure monitoring system, gas flow monitoring and quantitative analysis systems (Fig. 1).

1. Experimental chamber. For safety purposes, the experimental chamber was milled from a single piece of rolled steel; the size of the chamber is $400 \times 300 \times 300 \mathrm{~mm}$; the wall thickness is $40 \mathrm{~mm}$, and it is fitted with a double " $\mathrm{O}$ " ring.

2. Stress loading system. This experimental device is a one-dimensional displacement experimental device, loading only the vertical stress by a backpressure stand and jack whose maximum force is $200 \mathrm{KN}$. There is a sensor between the jack and the backpressure stand which allows for computerized control of the applied pressure.

3. Gas injection system. The gas injection system consists of cylinders, control valves, and injection gas line. The controls include a main valve and a pressure relief valve whose ranges are $0 \sim 25 \mathrm{MPa}$ and $0 \sim 6 \mathrm{MPa}$, respectively. The former controls the main valve display tank pressure, while the latter can control the injection pressure.

4. Vacuum pumping system. The experimental device is connected to a vacuum pump after it passes a tightness check and is safeguarded against leaking, then the pump is started, using a gauge to monitor the system vacuum in real-time.

5. Pressure monitoring system. The chamber has test holes in the side and by varying the position of the hollow tube inserted into coal with pressure sensors, it is possible to monitor the internal pressure of coal, using computer acquisition of the pressure data.

6. Gas flow monitoring system. This system quantifies the gas injection and discharge. Injection gas was metered by a mass flow controller with a maximum of $5 \mathrm{l} / \mathrm{min}$, and the instantaneous flow and total flow were monitored through the monitor.

7. Gas composition analysis system. During the displacement process, small gas samples were collected using 11 sample bags at certain times from the outlet on the gas meter, while composition and concentration of the gas samples were determined by gas chromatography. 
(a)

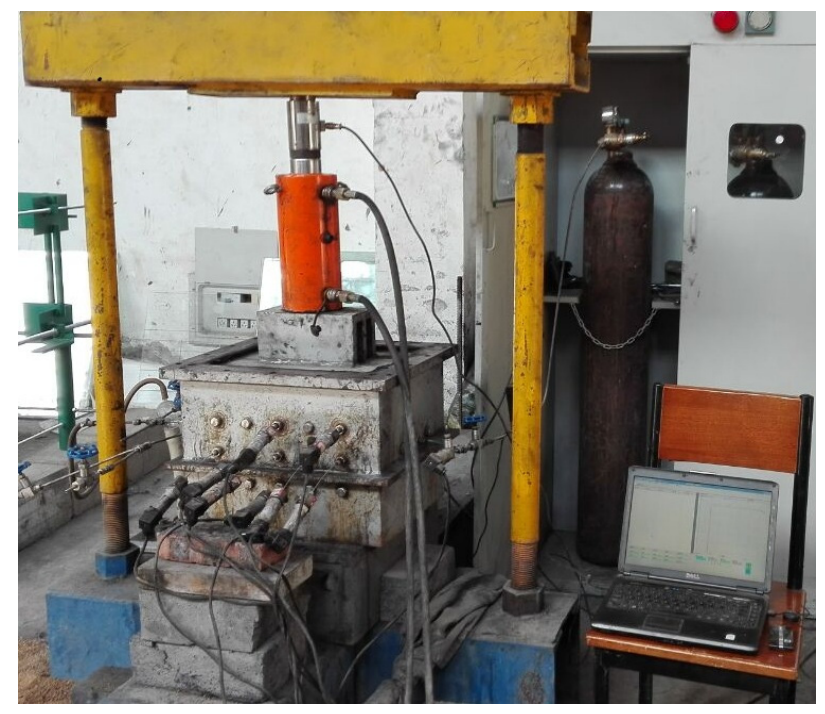

(b)

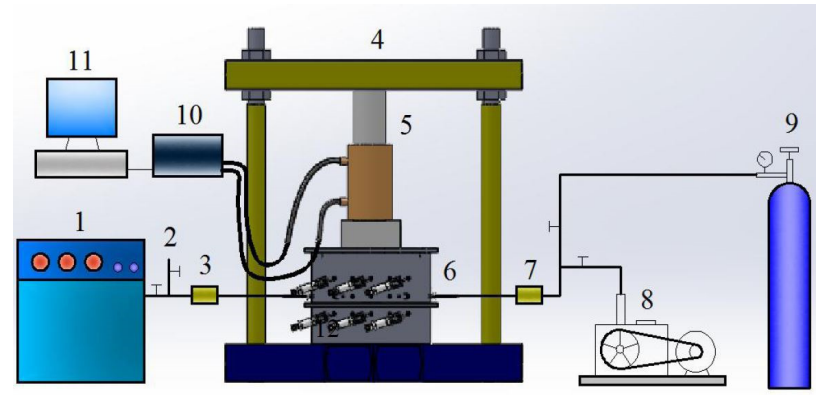

Figure 1. Experimental system: (a) general view; (b) schematic diagram; 1 -gas chromatograph; 2 - gas collecting mouth; 3 -low pressure flow meter; 4 - counterforce frame; 5-hydraulic jack; 6-chamber; 7 -high pressure flow meter; 8-vacuum pump; 9 -pressure steel bottle; 10 -pressure controller; 11 -pressure monitoring computer; 12 -pressure sensor

\subsection{Experimental coal sample}

An experimental coal loading method was used to take granular coal-like layered loading and conduct precompression molding, as shown in Table 1. The characteristics of the experimental coal samples are $4.54 \%$ water, $14.66 \%$ ash, $8.43 \%$ volatile matter, $1.76 \mathrm{t} / \mathrm{m}^{3}$ true density, $1.68 \mathrm{t} / \mathrm{m}^{3}$ apparent density and 0.15 solidity.

\subsection{Experimental procedure}

1. Vacuum pumping. The system is connected to a vacuum pump and held under vacuum at $500 \mathrm{~Pa}$.

2. Filling with $\mathrm{CH}_{4}$ to adsorption equilibrium. $\mathrm{CH}_{4}$ was provided by high-pressure cylinders; the outlet of a cylinder was connected with valve, and the coal sample was filled with $\mathrm{CH}_{4}$ until adsorption equilibrium was achieved at $0.7 \mathrm{MPa}$. To ensure complete adsorption of methane, this process requires no less than $48 \mathrm{~h}$.

3. Deflation. After achieving adsorption equilibrium, the gas injection outlet was opened, and the high-pressure free gas was released until the pressure dropped to $0.1 \mathrm{MPa}$. The volume of gas emitted was measured with a gas meter.

4. Gas injection. Upon completion of step (3), $\mathrm{N}_{2}$ was immediately injected into the chamber using the valve to control the injection pressure, while the gas input and output were measured with a flow meter and a gas meter.

5. Outlet gas collection. Gas was collected regularly from the outlet during the displacement process, gas meter and flow readings were recorded at the time of each gas collection; these gas samples were analyzed by gas chromatography to determine the end time of the displacement process.

6 . Relief of pressure. Once the concentration of methane in outlet was approximately $15 \%$, the gas injection port was closed, stopping the gas injection. Next, the gas in the chamber was allowed to escape.

7. End of the experiment. When the gas pressure of the chamber was down to $0.1 \mathrm{MPa}$, the outlet was closed, ending the experiment. Steps (1) to (7) were then repeated for the next set of experiments.

Table 1. Experimental coal sample collection and loading method

\begin{tabular}{cccccccc}
\hline Coal sample collection site & Coal & Granularity & $\begin{array}{c}\text { Loading } \\
\text { method }\end{array}$ & $\begin{array}{c}\text { Loading } \\
\text { level }\end{array}$ & $\begin{array}{c}\text { Stratified } \\
\text { thickness }\end{array}$ & $\begin{array}{c}\text { Preliminary } \\
\text { pressure }\end{array}$ & $\begin{array}{c}\text { Preload } \\
\text { time }\end{array}$ \\
\hline $\begin{array}{c}\text { No. } 2 \text { coal seam in Huatai } \\
\text { Coal Mine, Dayugou River, } \\
\text { Henan Province }\end{array}$ & Anthracite & $<1 \mathrm{~mm}$ & $\begin{array}{c}\text { Layered } \\
\text { loading } \\
\text { preloading }\end{array}$ & 4layers & $\begin{array}{c}40+80+80+ \\
+120 \mathrm{~mm}\end{array}$ & $120 \mathrm{kN}$ & $2 \mathrm{~min}$ \\
\hline
\end{tabular}

\section{EXPERIMENTAL RESULTS AND ANALYSIS}

We carried out the experimental displacement of coal methane by $\mathrm{N}_{2}$ injection according to the above steps. We obtained information regarding the process by monitoring the flow of $\mathrm{N}_{2}$ pressure, pore pressure of the experiment chamber, and the flow of produced gas and by determining the gas composition.

\subsection{Dependence of $\mathbf{N}_{2}$ injection and gas discharge on the flow change}

It can be seen in Figure 2 that initially, the flow of $\mathrm{N}_{2}$ injection is larger and continues to decline. The flow of the produced gas increases rapidly and evenly across the coal seam. The higher the pressure of injection, the greater the steady state flow rates of $\mathrm{N}_{2}$ injection and gas production. Under the same gas injection pressure, the steady state flow of the produced mixed gas is greater than that of gas injection. When the pressure of gas injection is $0.6 \mathrm{MPa}$, the steady state flow of $\mathrm{N}_{2}$ injection is $0.33 \mathrm{l} / \mathrm{min}$ and the steady state flow of the produced mixed gas is $0.5 \mathrm{l} / \mathrm{min}$.

When the pressure of gas injection is $1.0 \mathrm{MPa}$, the steady state flow of $\mathrm{N}_{2}$ injection is $1.0 \mathrm{l} / \mathrm{min}$, and the steady state flow of the produced mixed gas is $1.2 \mathrm{l} / \mathrm{min}$. When the pressure of gas injection is $1.4 \mathrm{MPa}$, the steady state flow of $\mathrm{N}_{2}$ injection is $2.3 \mathrm{l} / \mathrm{min}$ and the steady state flow of the produced mixed gas is $2.5 \mathrm{l} / \mathrm{min}$. 


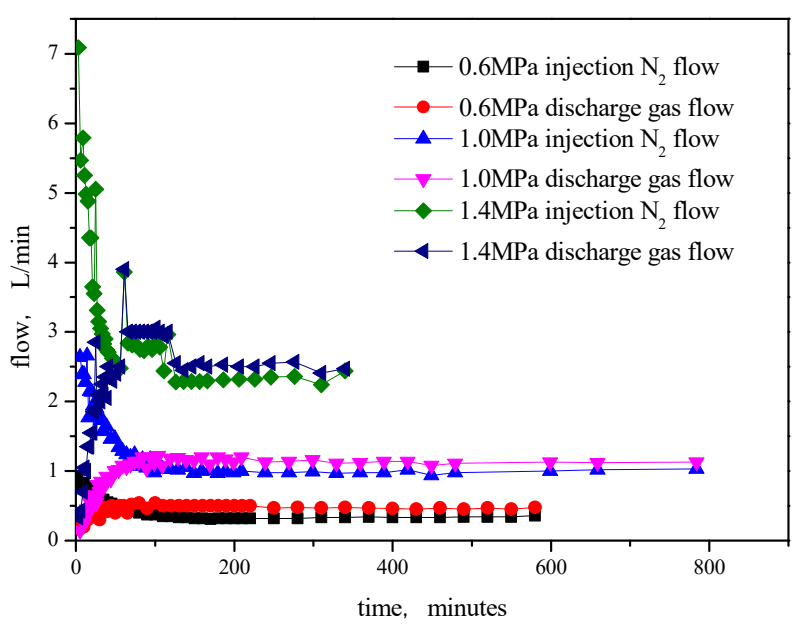

Figure 2. Dependence of $\mathrm{N}_{2}$ injection and mixed gas discharge on the flow change with injection time

(a)

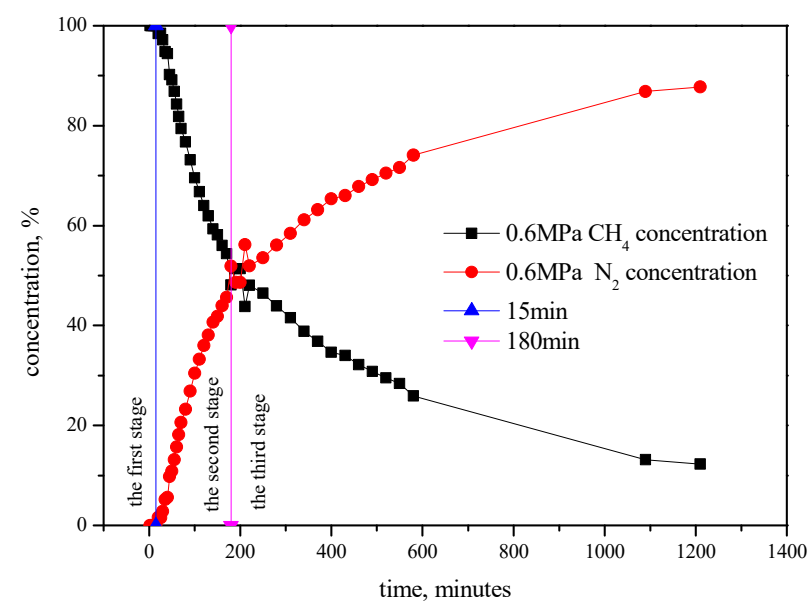

(c)

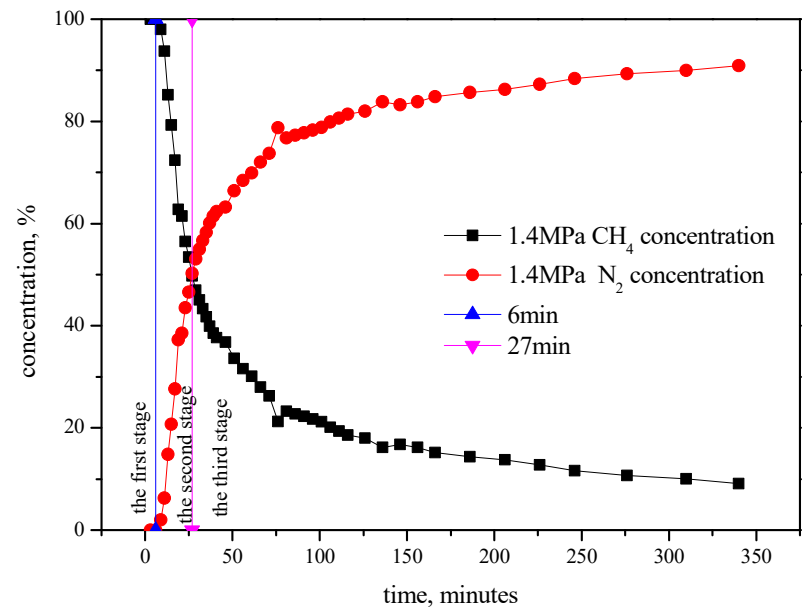

\subsection{Discharge gas concentration changes} the dependence and $\mathrm{N}_{2}$ breakthrough time

The change in the discharge mixed gas concentration throughout the experiment is shown in Figure 3.

It can be seen from Figure 3 that the initial period of gas injection can only be detected in the outlet $\mathrm{CH}_{4}$ discharge, $\mathrm{N}_{2}$ is not discharged but retained in the coal with the continuous injection of $\mathrm{N}_{2}, \mathrm{CH}_{4}$ concentration and $\mathrm{N}_{2}$ concentration. As the rate of change gradually slows, we will refer to the elapsed time to this point from the start of the gas injection as the $\mathrm{N}_{2}$ breakthrough time.

When the gas injection pressure is $0.6 \mathrm{MPa}$, the breakthrough time of $\mathrm{N}_{2}$ is $15 \mathrm{~min}$. When the gas is injected for $120 \mathrm{~min}$, the concentration of $\mathrm{CH}_{4}$ is reduced to $50 \%$ and the $\mathrm{N}_{2}$ concentration is increased to $50 \%$. At the end of gas injection $(1210 \mathrm{~min})$, the concentration of $\mathrm{CH}_{4}$ decreased to $12.27 \%$ and the $\mathrm{N}_{2}$ concentration increased to $87.73 \%$.

(b)

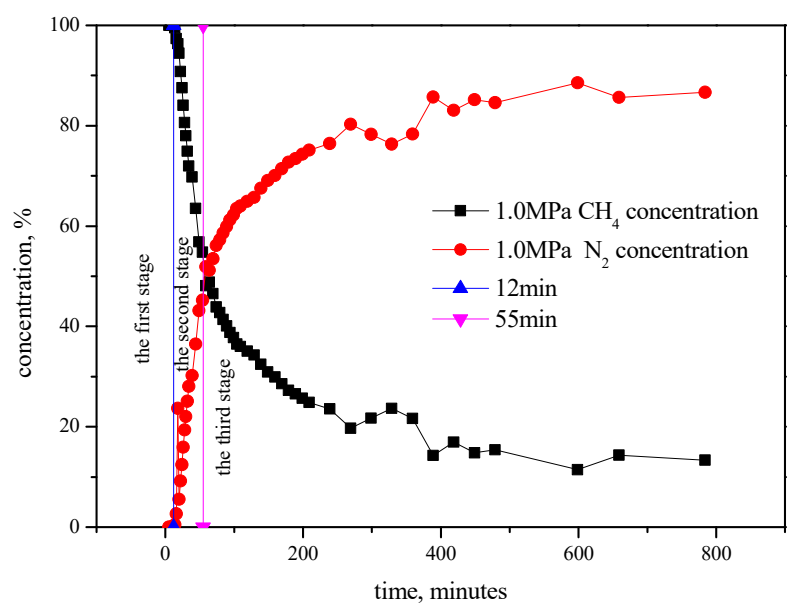

(d)

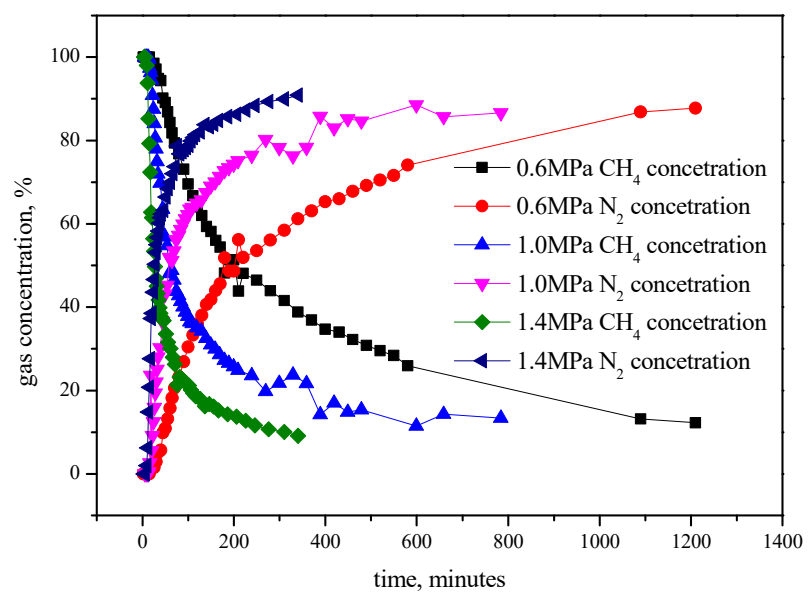

Figure 3. Dependence of discharged mixed gas concentration on the injection time: (a) $0.6 \mathrm{MPa}$; (b) $1.0 \mathrm{MPa}$; (c) $1.4 \mathrm{MPa}$; (d) 0.6 - $1.4 \mathrm{MPa}$

When the gas pressure was 1.0 MPa, the breakthrough time of $\mathrm{N}_{2}$ was $12 \mathrm{~min}$. When the gas injection time was $55 \mathrm{~min}$, the concentration of $\mathrm{CH}_{4}$ decreased to $50 \%$ and the concentration of $\mathrm{N}_{2}$ increased to $50 \%$. At the end of gas injection (784 $\mathrm{min})$, the concentration of $\mathrm{CH}_{4}$ decreased to $13.36 \%$ while that of $\mathrm{N}_{2}$ increased to
$86.64 \%$. When the gas pressure was $1.4 \mathrm{MPa}$, the breakthrough time of $\mathrm{N}_{2}$ was $6 \mathrm{~min}$. When the gas was injected for $27 \mathrm{~min}$, the concentration of $\mathrm{CH}_{4}$ decreased to $50 \%$ and the concentration of $\mathrm{N}_{2}$ increased to $50 \%$. At the end of gas injection (340 min), the concentration of $\mathrm{CH}_{4}$ decreased to $9.12 \%$ and that of $\mathrm{N}_{2}$ increased to $90.88 \%$. 


\subsection{Changes in the flow and volume of discharged $\mathrm{CH}_{4}$ with injection time}

The change of $\mathrm{CH}_{4}$ flow rate over the course of the experiment is shown in Figure 4; the change of $\mathrm{CH}_{4}$ volume is shown in Figure 5.

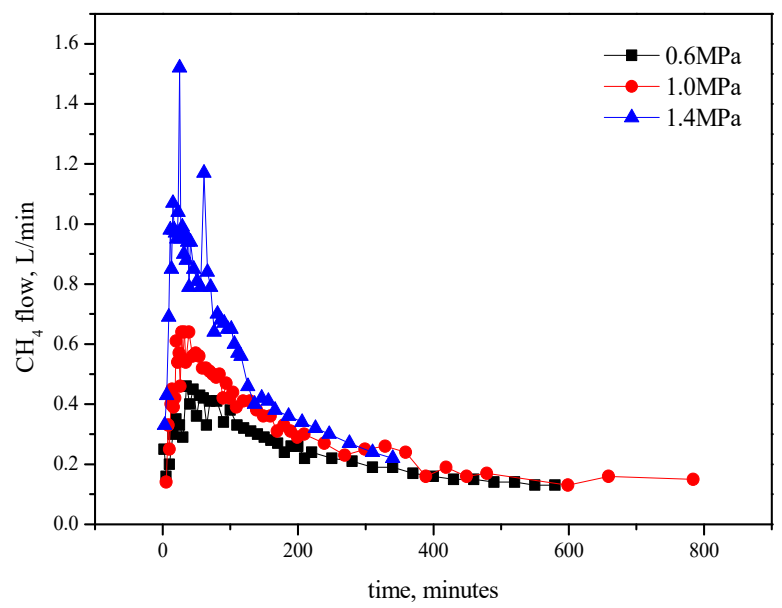

Figure 4. Dependence of flow change on $\mathrm{CH}_{4}$ discharge with injection time

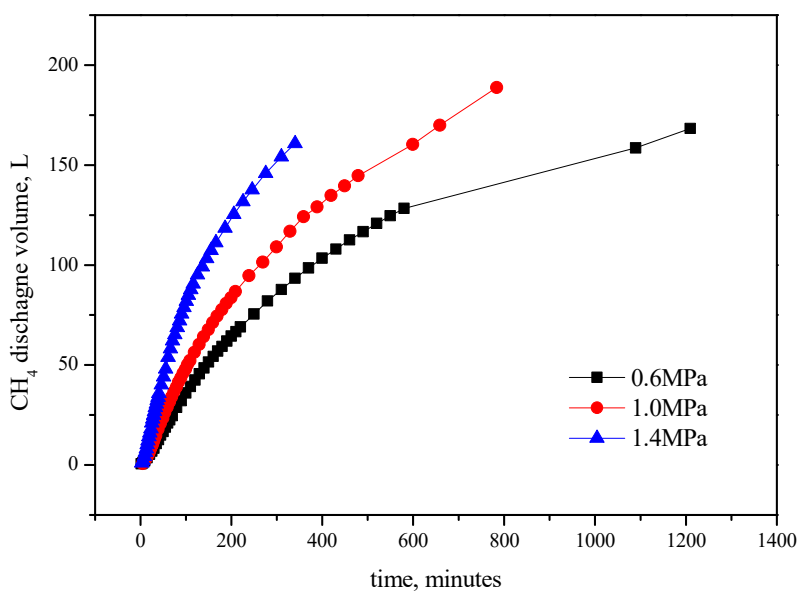

Figure 5. Dependence of volume change on $\mathrm{CH}_{4}$ discharge with time

It can be seen from Figure 4 that the flow rate of discharged $\mathrm{CH}_{4}$ increases at first and then declines. Under different gas pressures, the discharged $\mathrm{CH}_{4}$ flow behaved differently. When the gas pressure was $0.6 \mathrm{MPa}$, the flow rate of $\mathrm{CH}_{4}$ increased rapidly over $35 \mathrm{~min}$ from 0.25 to $0.46 \mathrm{l} / \mathrm{min}$. Then, with the continued injection of $\mathrm{N}_{2}, \mathrm{CH}_{4}$ flow decreased slowly, and the flow rate became steady at $0.15 \mathrm{l} / \mathrm{min}$. When the gas pressure was $1.0 \mathrm{MPa}$, the flow rate of $\mathrm{CH}_{4}$ increased rapidly over $28 \mathrm{~min}$ from 0.14 to $0.64 \mathrm{l} / \mathrm{min}$, and the flow rate became steady at approximately $0.15 \mathrm{l} / \mathrm{min}$. When the gas pressure was $1.4 \mathrm{MPa}$, the flow rate of $\mathrm{CH}_{4}$ increased rapidly over $28 \mathrm{~min}$ from 0.33 to $1.07 \mathrm{l} / \mathrm{min}$, and the flow rate became steady at $0.22 \mathrm{l} / \mathrm{min}$ by the end of gas injection. In the initial phase of the gas injection, the higher the gas injection pressure, the higher the $\mathrm{CH}_{4}$ flow rate. But with increased gas injection time, the $\mathrm{CH}_{4}$ flows with various gas injection, gas pressures gradually converged to $0.2 \mathrm{l} / \mathrm{min}$ or less.
It can be seen from Figure 5, that under different gas injection pressures, the total volume of discharged $\mathrm{CH}_{4}$ showed obvious differences. The higher the gas injection pressure, the greater the total amount of $\mathrm{CH}_{4}$ discharged in the same time, indicating that there is a positive correlation between the injection pressure and the effect of flooding. The total volumes of discharged $\mathrm{CH}_{4}$ were $92.5,120.8$ and 160.91 when the gas injection pressures were $0.6,1.0$ and $1.4 \mathrm{MPa}$, respectively.

\subsection{Change over time in the $\mathrm{N}_{2}$ volume retained in coal}

Under the experimental conditions, the time of gas injection in nitrogen gas, discharge of nitrogen and its retention in coal are shown in Figure 6.

It can be seen from Figure 6 that before $\mathrm{N}_{2}$ breaking through the chamber, all the nitrogen injected into the coal (the initial gas injection) is retained in the coal. At the beginning of gas injection, the volume trapped in coal rises sharply, and then tends to be stable. The greater the pressure of gas, the greater the volume of gas retention. When the gas pressure is $0.6 \mathrm{MPa}$, and before $\mathrm{N}_{2}$ breaking through (the $15^{\text {th }}$ minute), the $\mathrm{N}_{2}$ volume trapped in the coal is 12.211 , and then the gas injection time is 120 mins, the $\mathrm{N}_{2}$ volume trapped in coal is $50 \mathrm{l}$, in the end, the $\mathrm{N}_{2}$ volume trapped in the coal is 71.101 at the end of the gas filling (the $1210^{\text {th }}$ minute). When the gas pressure is $1.0 \mathrm{MPa}$, and before $\mathrm{N}_{2}$ breaking through the chamber (the $12^{\text {th }}$ minute), the $\mathrm{N}_{2}$ volume trapped in the coal is 29.761 , and then the gas injection time is 120 mins, the $\mathrm{N}_{2}$ volume trapped in the coal is $120 \mathrm{l}$, in the end, the $\mathrm{N}_{2}$ volume trapped in the coal is 165.691 at the end of gas filling (the $784^{\text {th }}$ minute). When the gas pressure is $1.4 \mathrm{MPa}$, and before $\mathrm{N}_{2}$ broking through the chamber (the $6^{\text {th }}$ minute), the $\mathrm{N}_{2}$ volume trapped in the coal is $37.68 \mathrm{l}$ and then the gas injection is $120 \mathrm{mins}$, the $\mathrm{N}_{2}$ volume trapped in the coal is 1901 , in the end, the $\mathrm{N}_{2}$ volume trapped in the coal is 221.321 at the end of gas filling (the $340^{\text {th }}$ minute).

\section{ANALYSIS OF THE PRINCIPAL EFFECT PRODUCED BY COAL SEAM GAS DISPLACEMENT}

\subsection{Quantitative determination of $\mathrm{CH}_{4}$ in coal injection}

The result of the experiment shows that the replacement of coal methane through gas injection is a dynamic process. The concentration and flow of $\mathrm{CH}_{4}$ produced changes in $\mathrm{N}_{2}$ injection pressure, flow and time, which shows that the process of replacement of coal seam methane by $\mathrm{N}_{2}$ injection is time dependent. To more clearly study the mechanism of the dynamic process of coal seam methane displacement by gas injection, this paper employs two definitions. Displacement effect: when injecting gas into coal, depending on the adsorption strength, a change in the $\mathrm{CH}_{4}$ partial pressure can turn the $\mathrm{CH}_{4}$ adsorption state into a free state. Replacement effect: when a new gas is injected into coal, the coal seam methane will discharge even with a low gas flow rate. 
(a)

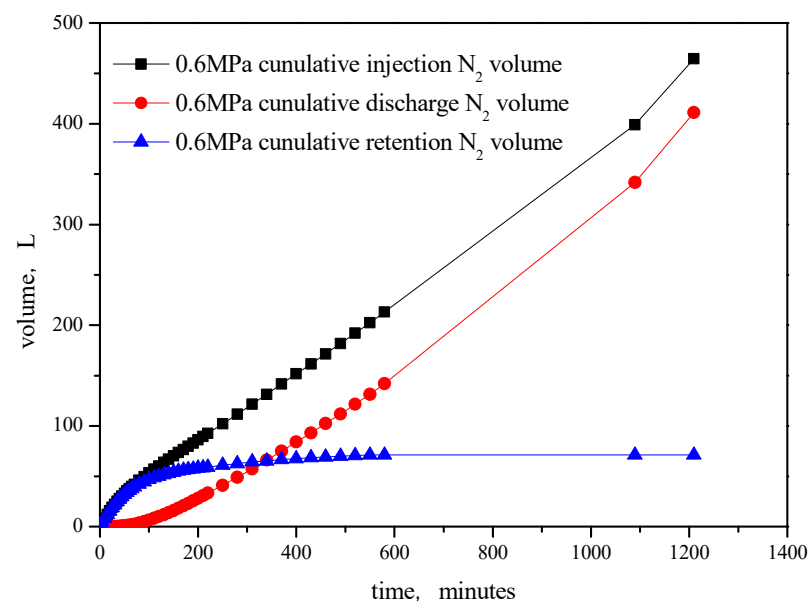

(c)

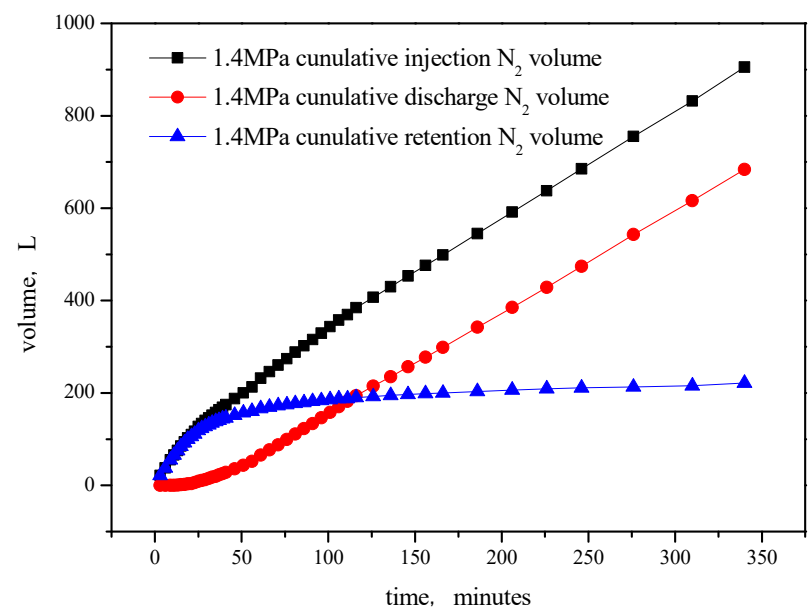

(b)

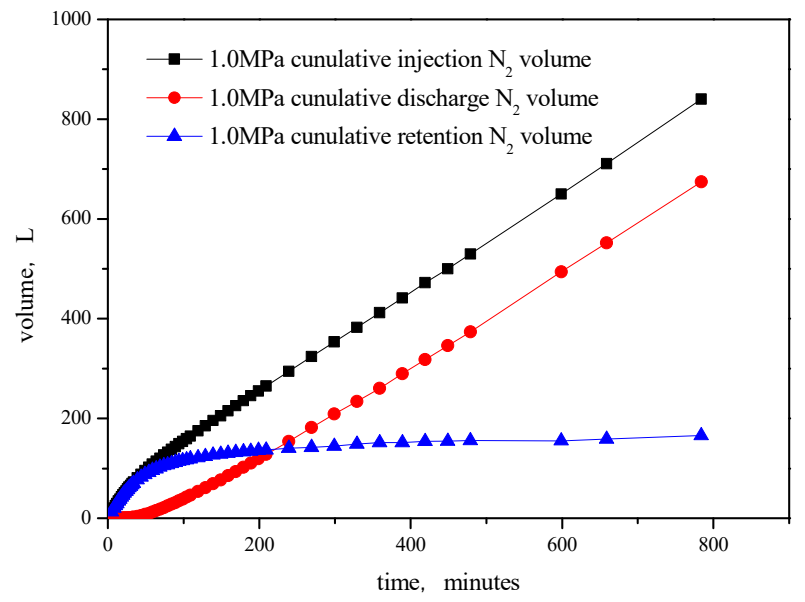

(d)

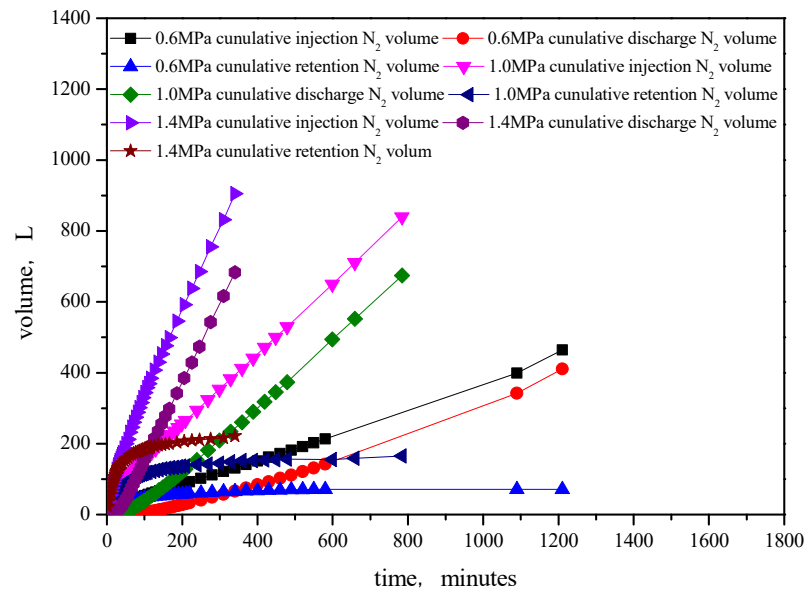

Figure 6. Cumulative volume change of injection of nitrogen, out of nitrogen, retention nitrogen in coal with time: (a) $0.6 \mathrm{MPa}$; (b) $1.0 \mathrm{MPa}$; (c) $1.4 \mathrm{MPa}$; (d) $0.6-1.4 \mathrm{MPa}$

This occurs because the gas injection will upset the $\mathrm{CH}_{4}$ adsorption equilibrium, which leads to a phenomenon in which $\mathrm{CH}_{4}$ will continue to desorb and discharge. The diagram of $\mathrm{CO}_{2}$-ECBM mechanism is shown in Figure 7, the diagram of $\mathrm{N}_{2}$-ECBM mechanism is shown in Figure 8.

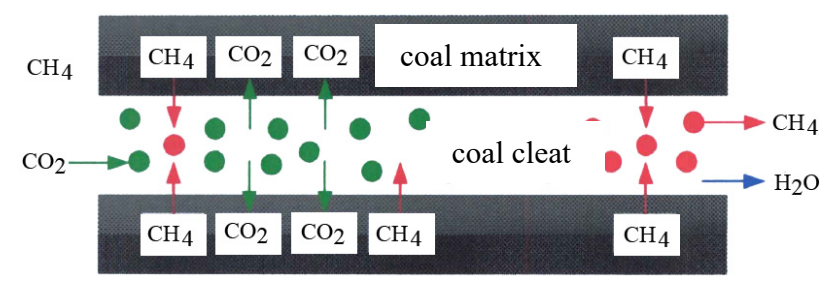

Figure 7. Diagram of $\mathrm{CO}_{2}-\mathrm{ECBM}$ mechanism

It can be seen that initially the flow rate of $\mathrm{N}_{2}$ injection is the same as the rate of $\mathrm{N}_{2}$ retention in the coal. $\mathrm{N}_{2}$ can upset the $\mathrm{CH}_{4}$ adsorption equilibrium and $\mathrm{CH}_{4}$ will desorb because of the partial pressure gradient, following Dalton's law during this process. The volume of $\mathrm{N}_{2}$ retained in the coal will displace the coal methane due to the displacement effect; as the available adsorptive capacity is reduced in the coal, the volume of $\mathrm{N}_{2}$ retained in coal also decreases rapidly.

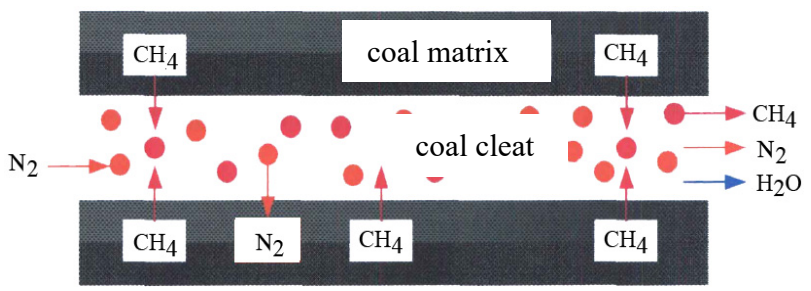

Figure 8. Diagram of $\mathrm{N}_{2}-\mathrm{ECBM}$ mechanism

As the injection time goes on, the flow rate of $\mathrm{N}_{2}$ injection reaches its steady state, and the $\mathrm{CH}_{4}$ desorbs continuously. A small quantity of $\mathrm{N}_{2}$ remains in the coal and occupies the remaining available adsorptive capacity. At this point, most of $\mathrm{N}_{2}$ is discharged with the flow of mixed gas. The volume of $\mathrm{N}_{2}$ discharged with the flow of gas which has replaced the coal methane can be thought of as the quantitative representation of the replacement effect.

We use the rates of displacement and replacement to quantitatively describe the changes in the balance between displacement and replacement. The rate of displacement is the ratio of $\mathrm{N}_{2}$ retained in the coal to $\mathrm{N}_{2}$ injected. The rate of replacement is the ratio of $\mathrm{N}_{2}$ discharged with the flow of mixed gas to $\mathrm{N}_{2}$ injected. 
$R_{d}=\frac{V_{r}}{V_{i}} \cdot 100 \%$,

where:

$R_{d}=$ the rates of displacement;

$V_{r}=1$ min volume of $\mathrm{N}_{2}$ remained in coal;

$V_{i}=1$ min volume of $\mathrm{N}_{2}$ injection.

$R_{r}=\frac{V_{d}}{V_{i}} \cdot 100 \%$,

where:

$R_{r}=$ the rates of replacement;

$V_{d}=1$ min volume of $\mathrm{N}_{2}$ discharged in coal;

$V_{i}=1$ min volume of $\mathrm{N}_{2}$ injection.

\subsection{Analysis of $\mathrm{CH}_{4}$ conversion process mechanism in $\mathrm{N}_{2}$ displacement coal}

According to the physical simulation experiment results treated above, it can be seen that at the initial stage of $\mathrm{N}_{2}$ injection, before the $\mathrm{N}_{2}$ breaks through the chamber (0.6, 1.0 and 1.4 MPa correspond to 15,12 and $6 \mathrm{~min}$ ), the $\mathrm{CH}_{4}$ concentration is $100 \%$, and the $\mathrm{N}_{2}$ concentration is $0 \%$. Since a large amount of free $\mathrm{CH}_{4}$ was predischarged before the experiment, the original adsorption equilibrium was broken, resulting in more desorption of $\mathrm{CH}_{4}$. At this time, there was a large amount of free adsorption sites in the coal. After $\mathrm{N}_{2}$ is injected into the coal, the $\mathrm{N}_{2}$ first occupies these adsorption sites, and there is some free space in the coal into which $\mathrm{N}_{2}$ continues to infuse. Meanwhile, the free space $\mathrm{N}_{2}$ partial pressure and the system total pressure both show an upward trend. At this point, $\mathrm{N}_{2}$ reaches the partial pressure at which it begins to sustain $\mathrm{CH}_{4}$ desorption, but on the other hand, from the molecular motion theory applied to the coal, a large amount of $\mathrm{N}_{2}$ adsorbs, exerting a certain hindrance on the adsorption of $\mathrm{CH}_{4}$. During this period, it is mainly the replacement effect of $\mathrm{N}_{2}$ which is manifest.

In the middle of the gas injection period, and $\mathrm{N}_{2}$ having recently broken through the chamber, $\mathrm{CH}_{4}$ and $\mathrm{N}_{2}$ gas can be detected together. The $\mathrm{CH}_{4}$ concentration decreases and the rate of this decrease lessens over time. On the other hand, the $\mathrm{N}_{2}$ concentration rises from 0 , rapidly at first and more slowly over time. The greater the pressure, the faster the change in gas pressure. In this process, the amount of methane adsorbed in the coal is the largest initially and the rate of desorption decreases rapidly. With the desorption, the amount of methane adsorbed in the coal decreases, and as the amount of methane available to desorb is decreasing, the amount of methane carried by $\mathrm{N}_{2}$ is also decreasing, and the rate of this decrease is gradually reduced. The overall increase in $\mathrm{N}_{2}$ concentration slows down over time. During this period, both the amount of $\mathrm{N}_{2}$ adsorbed and the amount of free $\mathrm{N}_{2}$ in the chamber are increasing. At the same time, part of the injected $\mathrm{N}_{2}$ will replace and desorb the $\mathrm{CH}_{4}$ which is discharged from the chamber. The carrying effect of $\mathrm{N}_{2}$ injection becomes evident, and part of the injected $\mathrm{N}_{2}$ begins to produce a flooding effect. As the gas injection progresses, the amount of $\mathrm{N}_{2}$ retained in the chamber is gradually increased, during which time the concentration of each component decreases, the gas flow rate gradually stabilizes, and the pressure rise in the chamber slows as the pressure reaches its steady state. The driving effect is gradually increased. At this time, $\mathrm{N}_{2}$ is injected, most of which carries $\mathrm{CH}_{4}$ out of the chamber; only a small part of $\mathrm{N}_{2}$ is adsorbed by the coal or is absorbed into the chamber free space; the cumulative retention of $\mathrm{N}_{2}$ in the chamber is now only slowly increased. Thus, the phase replacement effect is weakened, and the flooding effect is enhanced.

At the end of the gas injection period, changes in the concentrations of the two gases are getting less and less pronounced. With the increase of the gas injection time, $\mathrm{N}_{2}$ is gradually approaching its adsorption equilibrium state; the adsorption of $\mathrm{N}_{2}$ is gradually slowing; gas flow at the outlet is basically stable and the chamber pressure tends to be stable. At this time, $\mathrm{N}_{2}$ in the chamber has reached an adsorption balance, i.e., the difference between the amounts of $\mathrm{N}_{2}$ injected and expelled is essentially constant, and the performance of the total retention of $\mathrm{N}_{2}$ tends to be stable. Since the $\mathrm{CH}_{4}$ partial pressure reduction rate is slowed and the total pressure in the chamber is constant, the replacement effect of $\mathrm{N}_{2}$ is already weaker than before, and the continuous displacement effect is maintained so that the weak displacement desorption is maintained and most of $\mathrm{CH}_{4}$ is now out of the chamber. From the three experimental sets, changes in the flow can also be observed in the late gas injection. Injection flow and discharge flow are very close to the two curves and close to the trend, and a large portion of the injected $\mathrm{N}_{2}$ subsequently exercises a flooding effect, and in the last part of the experiment, the main effect of $\mathrm{N}_{2}$ is observed through flooding.

\subsection{Analysis of $\mathrm{CH}_{4}$ dominant function and contribution degree in $\mathrm{N}_{2}$-ECBM experiment}

In the above section, we analyzed the mechanism of the $\mathrm{CH}_{4}$ transformation process in $\mathrm{N}_{2}$ flooded coal at different times of the gas injection. What are the respective contributions of replacement and displacement in the overall gas injection experiment? In this section, we will conduct a whole analysis of this subject.

Under the experimental conditions, the cumulative replacement ratio, volume and displacement ratio, volume changes with time are shown in Figures 9-11.

When gas injection pressure is $0.6 \mathrm{MPa}$, the whole test duration is $580 \mathrm{~min}$. The replacement percentage decreased from $100 \%$ to $36.70 \%$, while the displacement percentage increased from $0 \%$ to $63.31 \%$. The volume of accumulated replaced gas is 47.111 , while that of accumulated displaced gas is 87.211 . The replacement percentage is equal to displacement percentage at $310 \mathrm{~min}$. Therefore, displacement is dominant during the whole test of $\mathrm{CH}_{4}$ replacement and displacement by $\mathrm{N}_{2}$.

When gas injection pressure is $1.0 \mathrm{MPa}$, the whole test duration is $784 \mathrm{~min}$. The replacement percentage decreased from $100 \%$ to $24.44 \%$, while the displacement percentage increased from $0 \%$ to $75.56 \%$. The volume of accumulated replaced gas is 46.211 , while that of accumulated displaced gas is 142.841 . The replacement percentage is equal to displacement percentage at $180 \mathrm{~min}$. Therefore, displacement is dominant during the whole test of $\mathrm{CH}_{4}$ replacement and displacement by $\mathrm{N}_{2}$. 
(a)

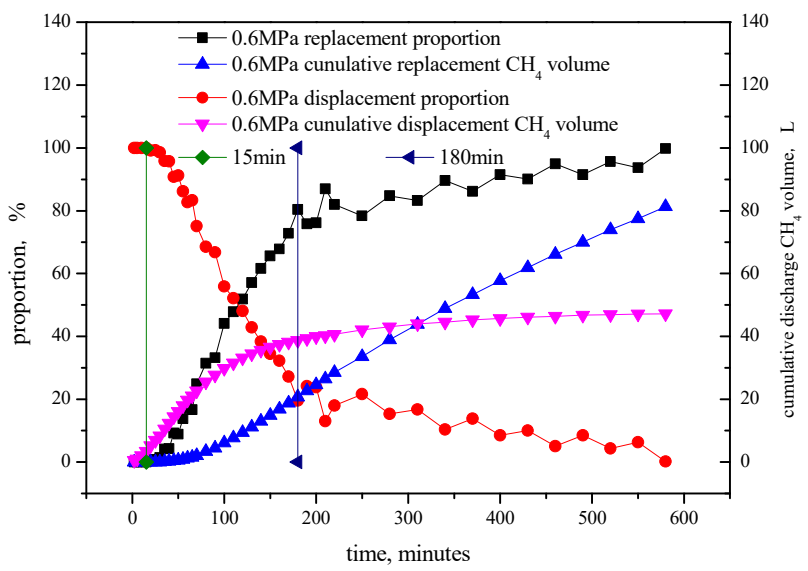

(b)

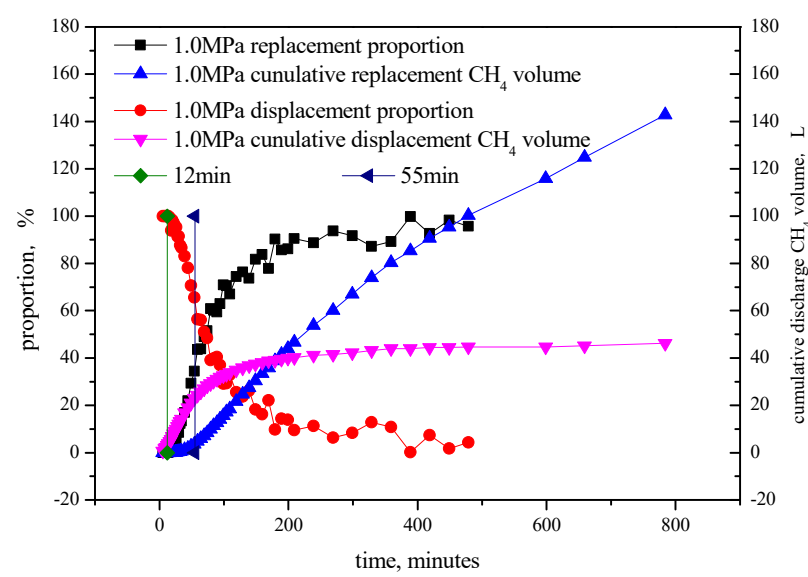

(c)

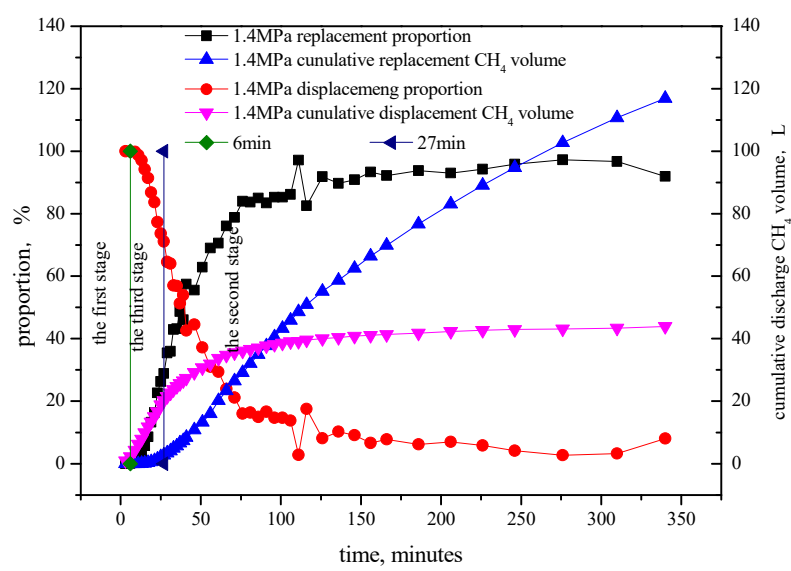

Figure 9. Change of displacement and replacement rate and volume with time: (a) $0.6 \mathrm{MPa}$; (b) 1.0 MPa; (c) $1.4 \mathrm{MPa}$

When gas injection pressure is $1.4 \mathrm{MPa}$, the whole test duration is $340 \mathrm{~min}$. The replacement percentage decreased from 100 to $27.32 \%$, while the displacement percentage increased from 0 to $72.68 \%$. The volume of accumulated replaced gas is 43.951 , while that of accumulated displaced gas is $116.91 \mathrm{l}$. The replacement percentage is equal to displacement percentage at $91 \mathrm{~min}$. Therefore, displacement is dominant during the whole test of $\mathrm{CH}_{4}$ replacement and displacement by $\mathrm{N}_{2}$.

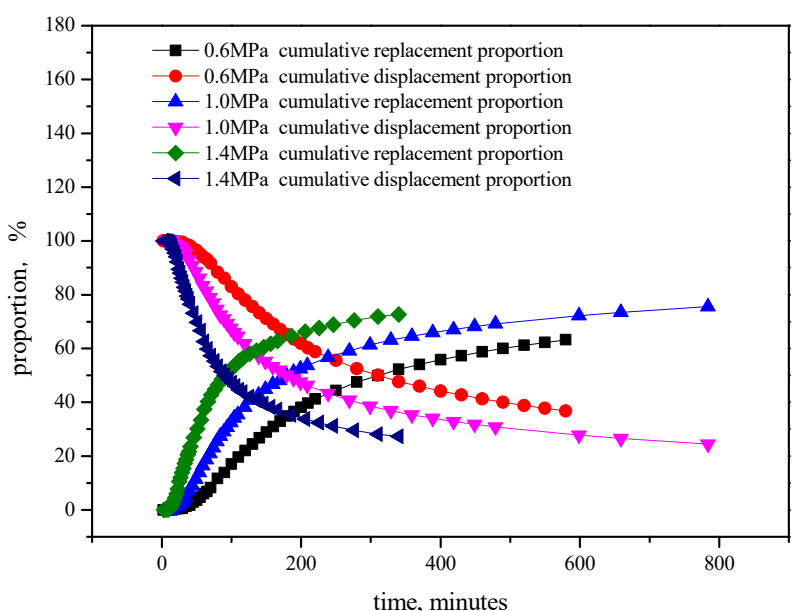

Figure 10. Change of displacement and replacement rate with time

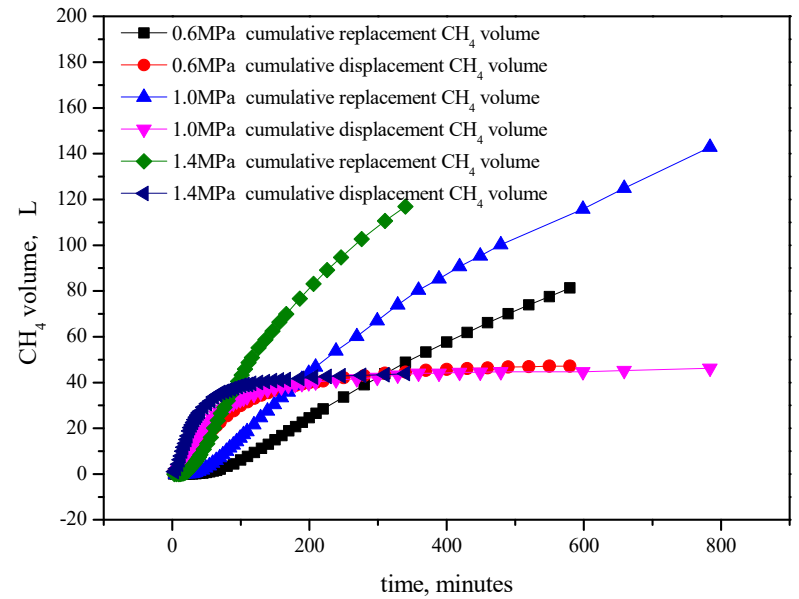

Figure 11. Change of displacement and replacement volume with time

\section{CONCLUSIONS}

Under the assumption of ideal gases, $\mathrm{N}_{2}$ can upset the adsorption balance of $\mathrm{CH}_{4}$ because of a partial pressure gradient based on Dalton's law of partial pressures. The volume of $\mathrm{N}_{2}$ which remains in the coal and displaces methane can be seen as the quantitative contribution of the displacement effect. If the coal seam methane discharged with the gas flow because of carrying of or driving the gas injection, then the volume of $\mathrm{N}_{2}$ discharged which will replace the coal methane can be seen as the quantitative contribution of replacement effect.

$\mathrm{N}_{2}$-ECBM experiment is a time-dependent process. Initially, all the injected $\mathrm{N}_{2}$ remains in the coal. This part of nitrogen only shows the replacement effect. As the time goes on, some of the injected $\mathrm{N}_{2}$ gradually begins to discharge. The displacement effect is decreasing, and the replacement effect is increasing. The rate of the replacement function is over $60 \%$, and the displacement function is $40 \%$, so the replacement plays a dominant role and the displacement plays a secondary role. 


\section{ACKNOWLEDGMENTS}

The authors are grateful for the financial support from the Natural Science Foundation for the Youth of China (No. 51404091) and the PhD Foundation of Henan Polytechnic University (B2015-08).

\section{REFERENCES}

Busch, A., Krooss, B.M., Gensterblum, Y., van Bergen, F., \& Pagnier, H.J.M. (2003). High-pressure adsorption of methane, carbon dioxide and their mixtures on coals with a special focus on the preferential sorption behaviour. Journal of Geochemical Exploration, 78-79(5), 671-674. https://doi.org/10.1016/s0375-6742(03)00122-5

China United Coal Bed Methane Corporation Ltd. (2007). China's CBM exploration and exploitation technical researches. Beijing, China: Petroleum industry press.

Clarkson, C.R., \& Bustin, R.M. (2000). Binary gas adsorption/desorption isotherms: effect of moisture and coal composition upon carbon dioxide selectivity over methane. International Journal of Coal Geology, 42(4), 241-271. https://doi.org/10.1016/s0166-5162(99)00032-4

Fitzgerald, J.E., Pan, Z., Sudibandriyo, M., Robinson, Jr.R.L., Gasem, K.A.M., \& Reeves, S. (2005). Adsorption of methane, nitrogen, carbon dioxide and their mixtures on wet Tiffany coal. Fuel, 84(18), 2351-2363. https://doi.org/10.1016/j.fuel.2005.05.002

Godec, M., Koperna, G., \& Gale, J. (2014). CO2-ECBM: a review of its status and global potential. Energy Procedia, (63), 5858-5869. https://doi.org/10.1016/j.egypro.2014.11.619

Gunter, W., Mavor, M., \& Robinson, J. (2005). $\mathrm{CO}_{2}$ storage and enhanced methane production: field testing at Fenn-Big Valley, Alberta, Canada, with application. Greenhouse Gas Control Technologies, (7), 413-421. https://doi.org/10.1016/b978-008044704-9/50042-2

Guo-ting, F. (2009). Low permeability of soft coal seam gas displacement technology practice in LuAn. Mining Safety \& Environmental Protection, (36), 90-93.

Hong-min, Y. (2010). Study on mechanism and characteristics laws of displacement coal bed methane by underground gas injection. Jiaozuo, China: Henan Polytechnic University.

Jian-guang, W., \& Xiao-guang, S. (2004). Research on mechanism of displacing coal-bed methane by injecting gas. China Coal, 30(12), 44-46.

Katayama, Y. (1995). Study of coal bed methane in Japan. In Proceedings of United Nations International Conference on Coal Bed Methane Development and Utilization (pp. 238-243). Beijing, China: Coal Industry Press.

Long-jun, X., Cheng-lun, L., \& Xue-fu, X. (2000). Exploration on the principle of ECMB. Journal of Chongqing University (Natural Science Edition), 23(6), 42-44.
Masoudian, M.S., Airey, D.W., \& El-Zein, A. (2014). Experimental investigations on the effect of $\mathrm{CO}_{2}$ on mechanics of coal. International Journal of Coal Geology, (128-129), 12-23. https://doi.org/10.1016/j.coal.2014.04.001

Oudinot, A.Y., Koperna, G.J., Philip, Z.G., Liu, N., Heath, J.E., Wells, A., \& Wilson, T. (2011). $\mathrm{CO}_{2}$ injection performance in the fruitland coal fairway, San Juan Basin: results of a field pilot. SPE Journal, 16(04), 864-879. https://doi.org/10.2118/127073-pa

Reeves, S. (2005). The Coal-Seq project: key results from field, laboratory, and modeling studies. Greenhouse Gas Control Technologies, (7), 1399-1403. https://doi.org/10.1016/b978-008044704-9/50155-5

Shang-chao, Z., \& Zhi-xu, D. (2008). Gas displacement in improving the innovation and application of the gas extraction rate. Coal Mine Safety, 405(8), 42-44.

Shi, J.-Q., Durucan, S., \& Fujioka, M. (2008). A reservoir simulation study of $\mathrm{CO}_{2}$ injection and $\mathrm{N}_{2}$ flooding at the Ishikari coalfield $\mathrm{CO}_{2}$ storage pilot project, Japan. International Journal of Greenhouse Gas Control, 2(1), 47-57. https://doi.org/10.1016/s1750-5836(07)00112-0

Shi-yue, W., \& Yong-yi, G. (2000). Analysis of mechanism of exploiting coal-bed methane by gas injection. Journal Taiyuan University of Technology, 31(4), 361-363.

Shu-heng, T., Qi, Y., \& Da-zhen, T. (2002). Study on the experiment and mechanism of raising the recovery ratio of coalbed methane by gas injection. Petroleum Geology \& Experiment, 24(6), 545-548.

Van Bergeb, F, Pagnier, H.J.M., van der Meer, L.G.H., van den Belt, F.J.G., Winthaegen, P.L.A., \& Westerhoff, R.S. (2002). Development of a field experiment of $\mathrm{CO}_{2}$ storage in coal seams in the Upper Silesian Basin of Poland (Recopol). Greenhouse Gas Control Technologies - $6^{\text {th }}$ International Conference, 569-574.

https://doi.org/10.1016/b978-008044276-1/50091-x

Wen-ming, G., \& Sui-an, Z. (2008). Research on enhance coalbed $\mathrm{CH}_{4}$ production rate by injecting gas under high temperature and high pressure. Inner Mongolia Petrochemical Industry, (14), 22-23.

Xiao-guang, S., \& Zhan-jun, J. (2004). Research on coalbed methane production rate by injecting gas under high temperature and high pressure. Energy Technology and Management, (2), 17-18.

Xi-jian, L., Li-yong, C., \& Hao, C. (2007). Discussion on effect mechanism of displacing coal-bed methane by injecting $\mathrm{CO}_{2}$ and $\mathrm{N}_{2}$. Express Information of Mining Industry, 469(8), 20-22.

Xing-zhou, Z., Yong-yi, G., \& Shi-yue, W. (2000). Analysis of technique of exploiting coal-bed methane by injecting gas. Journal Taiyuan University of Technology, 31(3), 251-253.

Zhi-ming, F., Xiao-chun, L., \& Hong, L. (2010). Feasibility study of gas mixture enhanced coal bed methane recovery technology. Rock and Soil Mechanics, 31(10), 3223-3229.

\section{МЕХАНІЗМ ПРОЦЕСУ ДЕГАЗАЦІї Й ЧАСОВІ ПАРАМЕТРИ ЗАСТОСУВАННЯ 그르ВМ ТЕХНОЛОГІЇ}

\section{Л. Чен, Т. Янг, Х. Янг, Л. Ванг}

Мета. Вивчити процес вприскування газу у вугільний пласт й механізм його впливу на основі технології, яка дозволяє забезпечити дренаж метану, інтенсифікований за рахунок нагнітання газу.

Методика. Використано експериментальний метод фізичного моделювання: була змонтована установка 3 моделлю вугленосного пласта для дослідження вприскування газу з метою витіснення метану. В експерименті попередньо стиснені зразки шаруватого вугілля піддавалися вертикальному навантаженню при тисках 200 кН, аналогічних тиску вприснутого газу. Газ для ін'єкцій вимірювався контролером масової витрати 3 максимальною швидкістю 5 л/хв, і через монітор контролювалися миттєвий і загальний потоки. В експерименті використано антрацит вугільної шахти Хуатай.

Результати. Експериментальними дослідженнями встановлено, що концентрація і об'єм метану призводять до змін тиску, витрати і часу вприскування азоту, що свідчить про те, що процес заміщення метану вугільного 
пласта шляхом закачування азоту залежить від часу. Доведено, що експеримент з використанням технології $\mathrm{N}_{2}$-ЕСВМ (інтенсивного вилучення вугільного метану) - це динамічний процес, в якому фактор часу відіграє вирішальну роль. Об'єм азоту, який залишається у вугіллі й витісняє метан, можна розглядати як кількісний вклад ефекту зміщення. Виявлено, що в результаті використання даної технології, рівень заміщення метану зріс більш, ніж на $60 \%$; а рівень його витіснення - на $40 \%$.

Наукова новизна. Вивчено ефект витіснення метану при нагнітанні азоту у вугільний пласт з урахуванням поведінки газу у вугленосній товщі, а також дана кількісна оцінка ефекту заміщення, що чинить ключовий вплив на всіх стадіях процесу, в той час як роль витіснення - другорядна.

Практична значимість. Результати експериментів мають принципове значення для оптимізації параметрів газу та для вибору джерела вприскування газу у вугільні пласти.

Ключові слова: механізм $N_{2}-E C B M$, фактор часу, ефект витіснення, ефект заміщення, кількісний аналіз, вугільна шахта

\title{
МЕХАНИЗМ ПРОЦЕССА ДЕГАЗАЦИИ И ВРЕМЕННЫЕ ПАРАМЕТРЫ ПРИМЕНЕНИЯ 글-ЕСВМ ТЕХНОЛОГИИ
}

\author{
Л. Чен, Т. Янг, Х. Янг, Л. Ванг
}

Цель. Изучить процесс впрыскивания газа в угольный пласт и механизм его воздействия на основе технологии, которая позволяет обеспечить дренаж метана, интенсифицированный за счет нагнетания газа.

Методика. Использован экспериментальный метод физического моделирования: была смонтирована установка с моделью угленосного пласта для исследования впрыскивания газа с целью вытеснения метана. В эксперименте предварительно сжатые образцы слоистого угля подвергались вертикальной нагрузке при давлениях 200 кН, аналогичных давлению впрыскиваемого газа. Газ для инъекций измерялся контроллером массового расхода с максимальной скоростью 5 л/мин, и через монитор контролировались мгновенный и общий потоки. В эксперименте использован антрацит угольной шахты Хуатай.

Результаты. Экспериментальными исследованиями установлено, что концентрация и объем метана приводят к изменениям давления, расхода и времени впрыска азота, что свидетельствует о том, что процесс замещения метана угольного пласта путем закачки азота зависит от времени. Доказано, что эксперимент с использованием технологии $\mathrm{N}_{2}$-ЕСВМ (интенсивного извлечения угольного метана) - это динамический процесс, в котором фактор времени играет решающую роль. Объем азота, который остается в угле и вытесняет метан, можно рассматривать как количественный вклад эффекта смещения. Выявлено, что в результате использования данной технологии, уровень замещения метана возрос более, чем на 60\%; а уровень его вытеснения - на $40 \%$.

Научная новизна. Изучен эффект вытеснения метана при нагнетании азота в угольный пласт с точки зрения поведения газа в угленосной толще, а также дана количественная оценка эффекту замещения, оказывающему ключевое влияние на всех стадиях процесса, в то время как роль вытеснения - вторична.

Практическая значимость. Результаты экспериментов имеют принципиальное значение для оптимизации параметров газа и для выбора источника впрыскивания газа в угольные пласты.

Ключевые слова: механизм $N_{2}-E C B M$, фактор времени, эффект вытеснения, эффект замещения, количественный анализ, угольная шахта

\section{ARTICLE INFO}

Received: 15 September 2018

Accepted: 4 December 2018

Available online: 10 December 2018

\section{ABOUT AUTHORS}

Liwei Chen, Master of Mining Engineering, Senior Lecturer of the Henan Polytechnic University, No. 2001, Century Road, High-tech District, 454000, Jiaozuo, China. E-mail: clwlf@163.com

Tianhong Yang, Doctor of Engineering Mechanics, Professor of the Northeastern University, No. 3-11, Wenhua Road, Heping District, 110819, Shenyang, China. E-mail: jjmksgt@126.com

Hongmin Yang, Doctor of Safety Science and Engineering, Professor of the Henan Polytechnic University, No. 2001, Century Road, High-tech District, 454000, Jiaozuo, China. E-mail: yhmfs@163.com

Liguo Wang, Doctor of Safety Science and Engineering, Associate Professor of the Henan Polytechnic University, No. 2001, Century Road, High-tech District, 454000, Jiaozuo, China. E-mail: wangliguofirst@163.com 